\title{
Britain launches two studies of 'Gulf War syndrome'...
}

London. Britain's Ministry of Defence (MoD) last week announced two epidemiological studies of illness among Gulf War veterans - two years after the US government set up a study on the possible link between US troops' exposure to chemical weapons during the war and their subsequent illnesses. by the Medical Research Council (MRC), and will be funded by the MoD at a total cost of $£ 1.32$ million (US\$2.2 million). Both studies will begin in January, and are expected to take three years.

The first British veterans with symptoms of 'Gulf War syndrome' came forward just months after the conflict ended in 1991. Symptoms range from skin rashes, headaches, nausea and musculoskeletal problems to depression. More than 900 such individuals have been examined under the MoD's 'medical assessment programme'.

So far, however, no evidence has emerged of a new pattern of illness specific to Gulf veterans. The MoD asked the MRC to recommend a direction for future research, for which proposals were invited last May. Two of these proposals have now been put forward by the MRC.

The new epidemiological studies will each compare 3,000 of the 50,000 UK Gulf veterans with 3,000 matched service personnel who did not go to the Gulf. In one study, Nicola Cherry and Alan Silman at the University of Manchester will look for statistical evidence of whether Gulf personnel report more ill-health, and whether they exhibit peculiar combinations of symptoms. "Our initial approach will be to question the troops directly," says Silman.

The second study will compare the reproductive health of Gulf and non-Gulf personnel, along with the health of their children. This work will be led by Patricia Doyle at the London School of Hygiene and Tropical Medicine.
The British projects have been selected

\section{IMAGE \\ UNAVAILABLE \\ FOR COPYRIGHT REASONS}

From soldiers to patients? Fresh studies will assess illness among Gulf War veterans.

If the results do indicate an excess of medical problems in Gulf personnel, then the scientists will need more detailed information about the occupational and environmental exposure of troops to hazardous substances. These include organophosphates (see box, below) and other pesticides sprayed into tents.

Other potential suspects include delousing powder used on Iraqi prisoners, vaccinations against transmissible diseases or biological weapons, chemical and biological weapons, and smoke from burning oil refineries, as well as diesel engines in or near tents.

"We are in negotiations with the MoD about what [information] is going to be needed and what access will be allowed," says Silman. The defence ministry has admitted that "medical record-keeping in the Gulf was not satisfactory".

A third study of known health problems and unexplained illness in 3,000 UK veterans and 6,000 controls is being funded by the US government.

Claire O'Brien

\section{...as minister apologizes for 'misleading'}

London. Nicholas Soames, the British armed forces minister, told the House of Commons last week that an investigation had revealed how parliament had been repeatedly misled on the question of whether troops had been exposed to organophosphates during the Gulf War.

$\mathrm{He}$ apologized for the fact that "flawed advice" originating from the Ministry of Defence had been presented by ministers since July 1994. The admission came during a statement in which Soames announced new research into

\section{the 'Gulf War syndrome'.}

Soames first admitted in October that organophosphate pesticides had been widely used to prevent troops from contracting flyborne diseases - in contrast to previous government statements that use of organophosphates was minimal.

The new information could be critical to the success of the new research, said Soames, because many of the health problems reported by Gulf War veterans could have been caused by exposure to organophosphates.
C. O'B.
Advances encourage Nobel winner to head AIDS vaccine effort
Washington. David Baltimore, the Nobel prizewinning biologist, said last week that the promise of recent advances in AIDS vaccine research had helped to persuade him to agree to lead the US National Institutes of Health (NIH)'s \$129-million vaccine research effort.

Baltimore, professor of molecular biology and immunology at the Massachusetts Institute of Technology, says that he decided to accept the job after launching his own investigation of developments in the field. "I wasn't going into something where it was my belief that it wasn't going to work. And I must say that I started off with some doubt," he says. What he found, he adds, "[has] given me a lot of hope that it is possible" to make a vaccine.

Among the advances that Baltimore said spurred his optimism were the discovery of the chemokine receptor, and the demonstration that monkeys can be protected with a live attenuated virus.

Announcing Baltimore's appointment last week, NIH officials said his gifts and experience are perfectly suited to the formidable task. "I'm very pleased," said Harold Varmus, director of NIH. "[David] has got a lot of exciting ideas. This dovetails ... with our determination to do something about HIV vaccines in the near future."

William Paul, director of the Office of AIDS Research, said that Baltimore's creativity, as well as his background as both an eminent virologist and molecular immunologist, will provide the kind of "visionary" leadership needed to develop a vaccine.

Working as a consultant to the National Institute of Allergy and Infectious Diseases (NIAID), Baltimore will oversee Baltimore: "visionary" vaccine research leadership for task. across the whole of NIH. He will also head an AIDS Vaccine Research Committee, which will be composed mainly of nongovernment scientists.

Baltimore, who was a co-discoverer of reverse transcriptase, and has done leading work on the polio virus, will spend about 20 per cent of his time coordinating the NIH's vaccine research. His appointment is a response to a recommendation of a review of AIDS research at NIH published last March by a working group led by Arnold Levine, a molecular biologist at Princeton University.

Meredith Wadman See also: AIDS research strategy (page 606) 